\title{
TRANSABDOMINAL ULTRASOUND AS A SCREENING STAGE FOR THE DIAGNOSIS OF TUBERCULOUS PERITONITIS
}

Plotkin $\mathrm{DV}^{1}, 2 \bowtie$, Kirillova OV${ }^{1}$, Nikanorov $\mathrm{AV}^{3}$, Reshetnikov $\mathrm{MN}^{1}$, Shtykhno $\mathrm{AO}^{1}$, Loshkareva $\mathrm{EO}^{2}$, Korotkova $\mathrm{ES}^{2}$, Sinitsyn $\mathrm{MV}^{1}$

${ }^{1}$ Moscow Research and Clinical Center for TB Control, Moscow, Russia

2 Pirogov Russian National Research Medical University, Moscow, Russia

${ }^{3}$ Loginov Moscow Clinical Scientific Practical Center, Moscow, Russia

In recent years, the incidence of tuberculous peritonitis increased. Peritoneal tuberculosis is difficult to diagnose, and often the diagnosis is verified with significant delay. In clinical practice, a quick and affordable diagnostic radiology method, ultrasonography (USG), is proposed for patients with suspected tuberculous peritonitis. The study was aimed to describe the sonographic semiology of tuberculous peritonitis, to create the integrated scale for the individual peritoneal tuberculosis sonographic symptoms significance assessment, and to determine the role of ultrasound imaging in the diagnosis verification. Retrospective study of the invasive and ultrasound investigation results of 37 patients with confirmed tuberculous peritonitis was carried out in 2009-2019. Similar data obtained by investigation of 28 patients with the disorders which often mimic the tuberculous peritonitis (peritoneal carcinomatosis and sarcoidosis, non-specific ascites) were used as a comparison group. Direct and indirect signs of peritoneal lesion in patients with tuberculosis were identified. On the basis of that, an integral scale for the individual sonographic symptoms significance assessment was created. Each sonographic symptom received a 0-3 score. Assessment of those sonographic signs visualization allowed us to evaluate the probability of the disorder's tuberculous etiology. The following data were obtained: score under 4 corresponded to low probability, score 5-8 corresponded to medium probability, and score over 9 corresponded to high probability of tuberculous peritonitis based on the visualization of all described songraphic symptoms. The proposed integrated scale for the sonographic signs assessment allows the clinician to verify the tuberculous peritonitis diagnosis based on the ultrasound imaging data or to select the further tactics of diagnosis.

Keywords: ultrasonography, peritoneal tuberculosis, peritonitis, carcinomatosis, sarcoidosis

Author contribution: Plotkin DV, Reshetnikov MN, Nikanorov AV, Sinitsyn MV - study concept and design, overall management; Kirillova OV, Shtykhno AO, Loshkareva EO — sample collection; Korotkova ES, Plotkin DV — statistical analysis; Plotkin DV, Reshetnikov MN, Kirillova OV, Nikanorov AV — data analysis; Plotkin DV, Reshetnikov MN — manuscript writing; Kirillova OV, Shtykhno AO, Nikanorov AV — editing.

Compliance with ethical standards: the study was approved by the Ethics Committee of the Moscow Research and Clinical Center for TB Control (protocol №.12 dated December 9, 2019). The informed consent was submitted by all study participants.

$\square$ Correspondence should be addressed: Dmitry V. Plotkin

Ostrovityanova, 1, Moscow, 117997; kn13@list.ru

Received: 17.03.2020 Accepted: 04.04.2020 Published online: 12.04.2020

DOI: $10.24075 / \mathrm{brsmu} .2020 .018$

\section{ТРАНСАБДОМИНАЛЬНОЕ УЛЬТРАЗВУКОВОЕ СКАНИРОВАНИЕ КАК СКРИНИНГОВЫЙ ЭТАП ДИАГНОСТИКИ ТУБЕРКУЛЕЗНОГО ПЕРИТОНИТА}

Д. В. Плоткин ${ }^{1,2} \bowtie$, О. В. Кириллова, А. В. Никаноров ${ }^{3}$, М. Н. Решетников ${ }^{1}$, А. О. Штыхно ${ }^{1}$, Е. О. Лошкарева², Е. С. Короткова², М. В. Синицын ${ }^{1}$

${ }^{1}$ Московский городской научно-практический центр борьбы с туберкулезом, Москва, Россия

2 Российский национальный исследовательский медицинский университет имени Н. И. Пирогова, Москва, Россия

${ }^{3}$ Московский клинический научный центр имени А. С. Логинова, Москва, Россия

За последние годы отмечен рост числа случаев туберкулезного перитонита. Туберкулез брюшины - сложный объект для диагностики и нередко верификация диагноза происходит со значительными задержками. В клинической практике предложен непродолжительный и доступный метод лучевой диагностики при подозрении на туберкулезный перитонит - ультразвуковое исследование (УзИ). Целью работы было описать эхо-семиотику туберкулезного перитонита с созданием интегральной шкалы оценки значимости отдельных эхо-симптомов туберкулеза брюшины и определить роль УЗ-сканирования в верификации диагноза. Произведен ретроспективный анализ инвазивной и УЗ-диагностики 37 пациентов с подтвержденным туберкулезным перитонитом в период с 2009 по 2019 г. В качестве группы сравнения использовали такие же данные исследований у 28 больных с заболеваниями, часто имитирующими туберкулезный перитонит (канцероматозом и саркоидозом брюшины, неспецифическим асцитом). Выделены прямые и косвенные признаки поражения брюшины при туберкулезе, на основании этого создана интегральная шкала оценки значимости отдельных эхо-симптомов. С этой целью каждому эхо-симптому присваивали от 0 до 3 баллов. При оценке визуализации описанных эхо-признаков возможно прогнозировать вероятность туберкулезной этиологии заболевания. Получены следующие статистические данные: низкая вероятность наличия туберкулезного перитонита при оценке визуализации всех описанных эхо-симптомов - до 4 баллов, средняя - от 5 до 8 баллов, высокая 9 и более баллов. Разработанная интегральная схема оценки УЗ-признаков позволяет клиницисту на основании эхографического исследования верифицировать туберкулезный перитонит или выбрать дальнейшую тактику в диагностическом поиске.

Ключевые слова: ультразвуковое исследование, туберкулез брюшины, перитонит, канцероматоз, саркоидоз

Вклад авторов: Д. В. Плоткин, М. Н. Решетников, А. В. Никаноров, М. В. Синицын - разработка концепции и дизайна исследования, общая ответственность; О. В. Кириллова, А. О. Штыхно, Е. О. Лошкарева - сбор материала; Е. С. Короткова, Д. В. Плоткин - статистическая обработка данных; Д. В. Плоткин, М. Н. Решетников, О. В. Кириллова, А. В. Никаноров - анализ полученных данных; Д. В. Плоткин, М. Н. Решетников подготовка текста; О. В. Кириллова, А. О. Штыхно, А. В. Никаноров - редактирование.

Соблюдение этических стандартов: исследование одобрено этическим комитетом Московского научно-практического центра борьбы с туберкулезом (протокол № 12 от 9 декабря 2019 г.). Все пациенты подписали добровольное информированное согласие.

$\bigotimes$ Для корреспонденции: Дмитрий Владимирович Плоткин

ул. Островитянова, д. 1, г. Москва, 117997; kn13@list.ru

Статья получена: 17.03.2020 Статья принята к печати: 04.04.2020 Опубликована онлайн: 12.04.2020

DOI: 10.24075/vrgmu.2020.018 
After the 45-year neglection, tuberculous peritonitis showed up again in European and Russian clinics. That was due to HIV pandemic, people's migration from endemic regions, emergence of extensively drug-resistant mycobacteria strains and drug-induced immunosuppression. Peritoneal tuberculosis (primary peritonitis) is a chronic inflammatory process with nonspecific clinical manifestations, which often causes significant difficulties and a delay in diagnosis [1-3]. According to the vast majority of scientists, the most accurate method of peritoneal tuberculosis verification is the diagnostic laparoscopic biopsy of the abdominal cavity serous membrane affected areas [4-5]. The growth of Mycobacterium tuberculosis (MTB) from exudates demonstrates the positive result 4-6 weeks after inoculation only in $10 \%$ of cases, and PCR analysis of effusion is informative in one-third of cases and also requires invasive intervention [5-6]. In clinical practice, short-term and affordable diagnostic radiology methods, ultrasonography and computed tomography $(\mathrm{CT})$, are the first choice for patients with suspected tuberculous peritonitis [1, 7, 8], however, in most cases, they do not allow one to identify the inflammatory process in the peritoneum accurately.

Ultrasonography is the most harmless, efficient and costeffective imaging method which can help clinicians to make decisions on the diagnosis and timely treatment of tuberculous peritonitis. Today, transabdominal ultrasound plays an important role in assessment of inflammatory, benign, and malignant diseases of the peritoneum, both in outpatient and inpatient settings. Medical literature describes different sonographic signs allowing one to suspect tuberculous peritonitis, as well as methods allowing one to distinguish between tuberculous peritonitis and peritoneal carcinomatosis or nonspecific ascites [7-11]. The accuracy of these methods depends on the qualification and experience of the doctor, as well as the class of equipment used. Over the past 10 years, most studies report the individual observations of the TB-associated peritoneal changes' visualization. However, there is no analysis of the prevalence of symptoms and their combinations $[9,11]$.

The study was aimed to describe the sonographic semiology of tuberculous peritonitis, to create the integrated scale for assessment of the significance of individual sonographic symptoms of peritoneal tuberculosis, and to determine the role of ultrasonography in the diagnosis verification.

\section{METHODS}

In 2009-2019, in the TB surgery department of the Hospital № 2 of the Moscow Research and Clinical Center for TB Control, Moscow, a retrospective study of the ultrasonography results of 37 patients with tuberculous peritonitis was carried out. The main clinical manifestation was a large volume of effusion in the abdominal cavity (exudative, adhesive, caseous and mixed forms of tuberculous peritonitis). Inclusion criteria: peritoneal tuberculosis diagnosed in all 37 patients via histological (100\%) and bacterioscopic (81.1\%) examination of peritoneal biopsies obtained using laparoscopic invasive methods. Among hospitalized patients, males predominated (22 men, 59.5\%; 15 women, 40.5\%) aged 20-65 (median age 37.2). Twenty three patients (62.7\%) were HIV-positive, 34 patients (91.6\%) had pulmonary tuberculosis, mostly the infiltrative and disseminated forms. Exclusion criteria: no histological confirmation of peritoneal tuberculosis.

For the comparison group, the patients were selected with the diseases verified using laparoscopy, histological and laboratory analysis data, which most often mimic tuberculous peritonitis, both in clinical picture and ultrasonography. The control group included 28 patients with non-specific ascites of various origin (21 patients; 75.0\%), peritoneal sarcoidosis (1 patient; 3.5\%) and peritoneal carcinomatosis (6 patients; $21.5 \%)$. The patients were aged 29-54 (median age 36.1). Pulmonary tuberculosis was diagnosed in all patients, 10 patients (35.7\%) of the control group were HIV-positive. Exclusion criteria for the control group: tuberculous granulomas and acid resistant mycobacteria in the peritoneal biopsy; mycobacterial DNA positive effusion PCR-test.

The patients were examined using polypositional radiography, thoracic computed tomography, abdominal ultrasonography, diagnostic video-assisted laparoscopy, laboratory and morphological techniques. Diagnostic studies were expanded using histological, cytological, and molecular genetic analysis of intraoperative material (biopsies and exudate). Microbiological studies included Ziehl-Neelsen (ZN) microscopy for acid-fast bacilli examination, inoculation of solid and liquid media using the automated systems.

Abdominal ultrasonography was performed using the Toshiba Aplio 500 expert-class ultrasound system (Toshiba; Japan) and the LOGIC ER7 portable imaging system (General

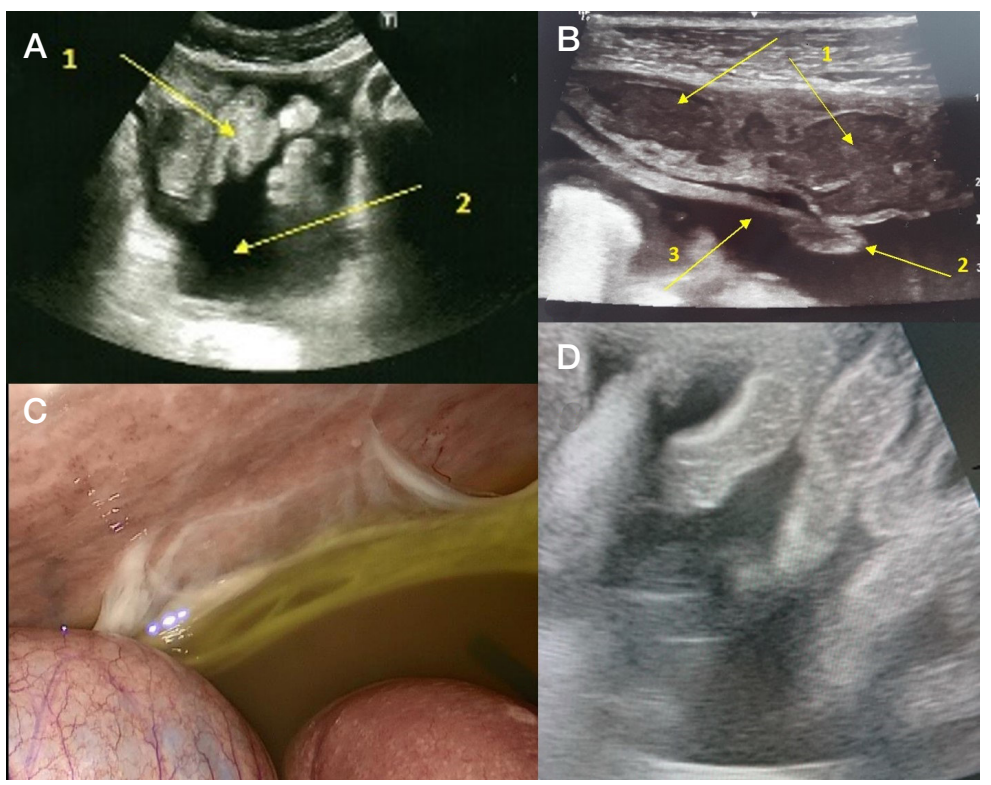

Fig. 1. Tuberculous peritonitis. A. Sonogram: 1 - paretic bowel loops, 2 - exudate. B. Sonogram: 1 - intra-peritoneal caseous abscess, 2 - tubercle, 3 - parietal peritoneum striated pattern. C. Laparoscopy. D. Sonogram: heterogeneous fibrinous effusion and paretic loops of the small intestine 


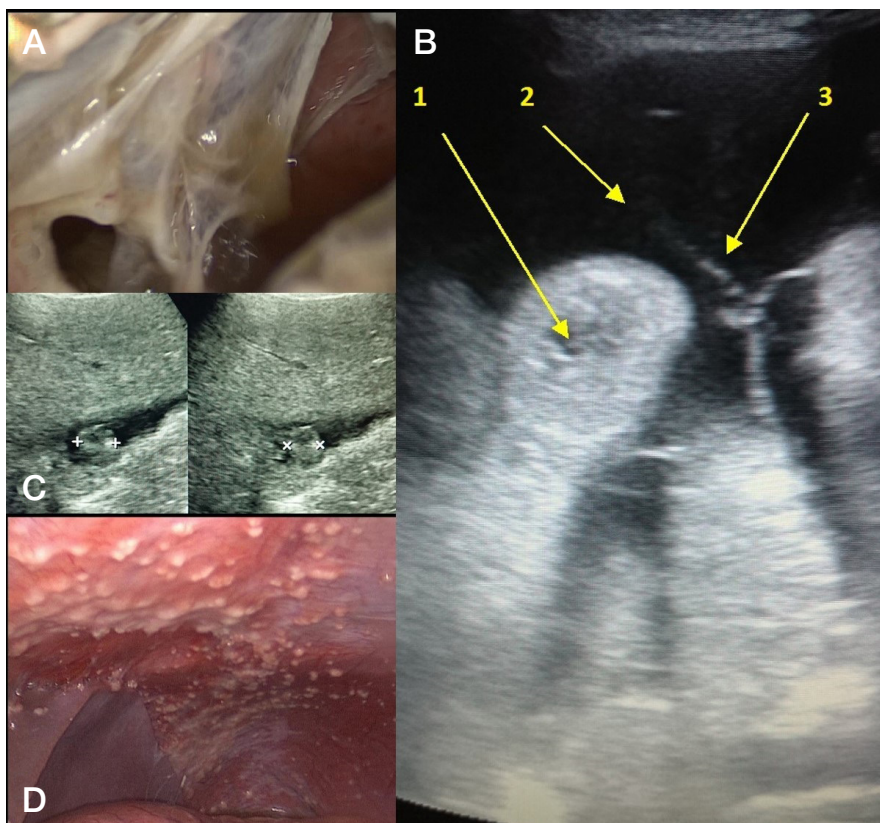

Fig. 2. Tuberculous peritonitis. A. Laparoscopy: fibrin overlays forming septa. B. Sonogram: 1 - intestinal loops, 2 - exudate, 3 - fibrin strands forming septa. C. Sonogram: tubercle (7 mm). D. Laparoscopy: tubercles on the parietal peritoneum

Electric; Republic of Korea) working in the grayscale, real-time mode. Abdominal cavity examination was carried out using the 2.5-5.0 MHz convex probe for assessment of presence and prevalence of free fluid, as well as the spleen and liver state. High-frequency linear probe (10-15 MHz) was used for evaluation of the intestinal loops, mesentery, greater and lesser omentum, lymphatic apparatus state.

Elective surgery (laparoscopic-assisted biopsy or laparotomy) was performed in patients with ascites of unknown origin or in order to clarify the nature of the pathological process detected by ultrasound imaging and computed tomography. Emergency surgery was performed in patients with clinical picture not allowing one to exclude peritonitis.

The criterion for the diagnosis verification was the detection of tuberculous granulomas in the peritoneum biopsy specimens, acid-fast bacilli during bacterioscopic examination and a positive result of PCR testing of effusion, as well as a combination of these signs.

Statistical analysis of the results was performed using standard statistical methods and the Statgraphics Centurion
18 software package (Statgraphics Technologies, Inc.; USA), Python 3.6 language (Python Software Foundation; USA) and Bayes' theorem [12]

\section{RESULTS}

To evaluate the sonographic symptoms of tuberculous peritonitis, we identified the following direct signs that were related to the inflammatory process in the serous leaflets and the associated exudation: presence of free fluid and its location in the abdominal cavity, exudate homogeneity, fibrin septa or incomplete septa in the abdominal cavity, striated pattern and heterogeneity of peritoneum and omentum, tubercles in serous leaflets.

Indirect signs of the peritoneum tuberculous lesions include the intestinal loops changes, spleen enlargement and heterogeneity, and the visualization of the enlarged mesenteric lymph nodes groups. Indirect signs do not reflect the inflammatory process in the peritoneal membranes, but may be the result of long-term ascites (thickening of the bowel walls),

Table 1. Direct and indirect signs of tuberculous peritonitis (the significance level is 0.95)

\begin{tabular}{|c|c|c|c|}
\hline Sonographic sign & $\begin{array}{l}\text { Tuberculous peritonitis } \\
\qquad n=37\end{array}$ & $\begin{array}{l}\text { Ascites and carcinomatosis } \\
\qquad n=28\end{array}$ & Sign character \\
\hline Free fluid in all abdominal cavity parts & $51.4 \% \pm 16.1$ & $82.1 \% \pm 14.1$ & \multirow{7}{*}{ Direct signs } \\
\hline Free fluid in pelvis and between intestinal loops & $21.6 \% \pm 13.2$ & $3.6 \% \pm 6.8$ & \\
\hline Encysted fluid & $27.0 \% \pm 14.3$ & $14.3 \% \pm 12.9$ & \\
\hline Heterogeneous effusion & $75.7 \% \pm 13.8$ & $3.6 \% \pm 6.8$ & \\
\hline $\begin{array}{l}\text { Striated pattern and heterogeneity of the parietal peritoneum } \\
\text { and omentum leaflets }\end{array}$ & $37.8 \% \pm 15.6$ & 0 & \\
\hline Intra-peritoneal caseous abscesses & $2.7 \% \pm 1.6$ & 0 & \\
\hline Peritoneal tubercles & $24.3 \% \pm 13.8$ & $10.7 \% \pm 11.5$ & \\
\hline Bowel wall thickening & $18.9 \% \pm 12.6$ & $21.4 \% \pm 15.2$ & \multirow{6}{*}{ Indirect signs } \\
\hline lleus & $16.2 \% \pm 11.9$ & $10.7 \% \pm 11.5$ & \\
\hline Splenomegaly & $13.5 \% \pm 11.0$ & $71.4 \% \pm 16.7$ & \\
\hline Enlarged and heterogeneous mesenteric lymph nodes & $51.4 \% \pm 16.1$ & $14.3 \% \pm 12.9$ & \\
\hline Enlarged liver and vascular pattern depletion & $27.0 \% \pm 14.3$ & $82.1 \% \pm 14.2$ & \\
\hline Expansion of the portal vein and diffuse changes of the liver & $8.1 \% \pm 8.8$ & $85.7 \% \pm 12.9$ & \\
\hline
\end{tabular}




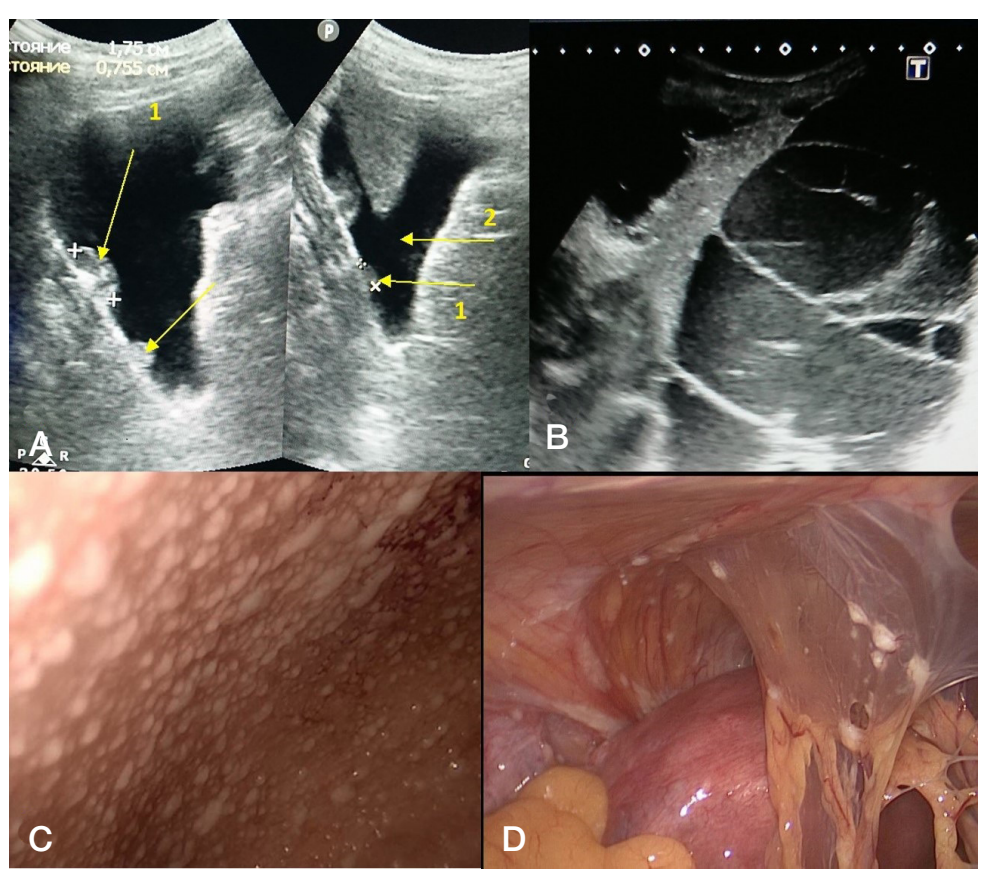

Fig. 3. Granulomatous peritonitis and carcinomatosis. A. Sonogram: peritoneal carcinomatosis associated with sigmoid colon cancer. 1 - disseminated tumors (17 and 8 mm), 2 - ascites. B. Sonogram: encysted ascites associated with ovarian cancer. C. Laparoscopy: parietal peritoneum carcinomatosis. D. Laparoscopy: peritoneal sarcoidosis

as well as the effect or specific lymphadenitis and splenitis in patients with abdominal tuberculosis.

When performing the abdominal ultrasound, various volumes of free fluid were detected in all patients with tuberculous peritonitis. The effusion in all parts of the abdominal cavity was visualized in 19 patients (51.4\%). In eight patients (21.6\%), free fluid was localized mainly in the pelvis and between the loops of the small intestine, and in 10 patients $(27.0 \%)$ the encysted free fluid was revealed together with the formation of incomplete or complete septa from fibrin layers. The effusion heterogeneity due to freely floating layers of fibrin and small fibrin sequestra with a diameter of up to $6-8 \mathrm{~mm}$ was noted in the vast majority of patients (75.7\%). Striated pattern and heterogeneity of certain areas of parietal peritoneum leaflets (primarily in the ileocecal region) were observed in 14 patients (37.8\%), moreover, in one patient, the caseous foci were visualized inside the anterior abdominal wall (Fig. 1). Heterogeneity and striated pattern of the greater omentum were found in 9 patients (24.3\%). Tubercles characteristic of tuberculous peritonitis were visualized in 9 patients (24.3\%). The tubercle size varied between 5-9 mm, tubercles were described as hyperechoic avascular foci with uneven contour rising above the parietal peritoneum (Fig. 1, 2).

The other features allowing one to suspect tuberculosis as the cause of peritoneal changes included the sonographic signs of the visceral peritoneum, spleen and mesenteric lymphatic apparatus involvement in the pathological process. Bowel wall changes were registered in 7 patients (18.9\%). Most comminly, there was a local thickening of the intestinal wall exceeding $3 \mathrm{~mm}$ with its length within 45-60 mm. In 6 patients (16.2\%), the expansion of the intestinal lumen of more than $33-35 \mathrm{~mm}$ and the weakening or complete absence of peristalsis were revealed, which was considered a paralysis. Enlarged mesenteric lymph nodes (more than 10-16 mm in diameter) with a heterogeneous structure were detected in 19 patients (51.4\%). Splenomegaly with spleen heterogeneity was observed in 5 patients (13.5\%). Comparison of the control group patients' ultrasonography results is presented in Table 1.

To create an integrated scale for assessment of the tuberculous peritonitis probability using ultrasongraphy, all variants of signs (sonographic symptoms) combinations were considered. For that, each sonographic symptom received a 0-3

Table 2. Integral table of sonographic symptoms occurrence in patients with tuberculous peritonitis

\begin{tabular}{|c|c|c|}
\hline \multicolumn{2}{|c|}{ Sonographic sign } & Score \\
\hline \multicolumn{2}{|c|}{ Free fluid in all abdominal cavity parts } & 1 \\
\hline \multicolumn{2}{|c|}{ Free fluid in pelvis and between intestinal loops } & 0 \\
\hline \multicolumn{2}{|c|}{ Encysted fluid in the abdominal cavity with septa } & 2 \\
\hline \multicolumn{2}{|c|}{ Heterogeneous effusion with fibrin fragments } & 2 \\
\hline \multicolumn{2}{|c|}{ Striated pattern and heterogeneity of the parietal peritoneum and omentum leaflets } & 3 \\
\hline \multicolumn{2}{|c|}{ Intra-peritoneal caseous abscesses } & 3 \\
\hline \multicolumn{2}{|c|}{ Peritoneal tubercles, diameter up to $9 \mathrm{~mm}$} & 3 \\
\hline \multicolumn{2}{|c|}{ Peritoneal tubercles, diameter over $9 \mathrm{~mm}$} & 0 \\
\hline \multicolumn{2}{|c|}{ Indirect signs: bowel wall changes and mesenteric lymphadenopathy } & 1 \\
\hline \multicolumn{3}{|c|}{ Tuberculous peritonitis probability } \\
\hline High & Medium & Low \\
\hline Score $\geq 9$ & Score 5-8 & Score $\leq 4$ \\
\hline
\end{tabular}


score. The 1st three signs (free fluid distribution) determined the 1 st complete event space, probability (effusion in the abdminal cavity). Tubercles of various sizes could be considered the 2 nd complete event space (based on the tubercle size). The other signs (heterogenous effusion with fibrin fragments, striated pattern and heterogeneity of parietal peritoneum and omentum leaflets, intra-peritoneal caseous abscesses) were independent. Next, calculations were made for all features combinations using Python 3.6 language and Bayes' theorem, allowing one to determine the probability based on the data provided. Assumptions about the approximation of binomial distributions to normal and the conclusion on the inclusion of patients in the groups (low, medium, high probability) were made using the stats and numpy libraries (Table 2.).

\section{DISCUSSION}

Thus, it can be noted that the visual signs of tuberculous peritonitis, benign peritoneal granulomatosis (sarcoidosis), nonspecific ascites, and peritoneal carcinomatosis are very similar and in most cases confront the researcher with a choice of diagnosis.

Our experience of ultrasound scanning in patients with tubercolous peritonitis, and the literature data [710] demonstrate that the main sonographic symptom is the presence of heterogenous free of encysted fluid in the abdominal cavity (75-80\%). A characteristic feature that allows one to distinguish tuberculous peritonitis from non-specific ascites is the more frequent (about $75 \%$ ) visualization of fibrin sequestrations freely floating in the exudate, which in sometimes form complete or incomplete septa causing the encysted effusion (Fig. 2). Nevertheless, similar sonographic features also occur in $50 \%$ of patients with peritoneal carcinomatosis [13]. Conversely, in patients with carcinomatosis, there is a high probability of disseminated tumors detection with a diameter of 5-18 mm (Fig. 3). Accoding to our data, similar hyperechoic foci on the peritoneum can also be detected in patients with benign granulomatosis, for example, with sarcoidosis (Fig. 3), which also does not give any reason to consider this feature specific. Tubercles in the peritoneum usually have a smaller diameter, and the maximum tubercle size is up to $9 \mathrm{~mm}$ (median value 4-6 mm) [11, 13-16]. A more reliable sonographic symptom of tuberculous peritonitis is the heterogeneity (striated pattern) of the parietal peritoneum and omentum areas, however, this symptom can be determined in just over one third of all cases. The most common finding is the extended hypoechoic thickening of the serous parietal leaflet $(4-8 \mathrm{~mm})$, which is associated with chronic inflammation. According to a number of authors, this variant of the thickened peritoneum is probably associated with tuberculosis [8, 17-20] and is less common in patients with peritoneal carcinomatosis, where the thickening of the serous membrane is most often small and nodular [20]. Various authors are equally likely to describe the involvement of the greater omentum and its changes as a characteristic sign of tuberculous omentitis or carcinomatosis, therefore we consider this symptom to be specific for both disorders, given that it is rarely possible to visualize the omental changes (less than 25\% of observations) [21].

Indirect signs of peritoneal damage, such as lymphadenopathy with adenomegaly, occur in half of patients with tuberculous peritonitis, which reflects the pathogenetic charater of lymphogenous dissemination in the peritoneal leaflets. The mesenteric lymphatic apparatus changes are most often destructive, and the lymph nodes are visualized as grouped anechogenic rounded foci with a diameter exceeding $10 \mathrm{~mm}$. According to the literature, the prevalence of joint lesions of intra-abdominal lymph nodes and peritoneum is 10 $54 \%$ [22-24].

Thus, it is clear that tuberculous peritonitis does not have any reference or unique sonographic symptoms, which makes it extremely difficult to diagnose it using ultrasound imaging. At the same time, various combinations of some direct and indirect signs increase the probability of the ultrasound image correct interpretation in patients with peritoneal tuberculosis.

Based on the calculations and the probability distribution, the following data has been obtained: score under 4 corresponds to low probability, score 5-8 corresponds to medium probability, and the score over 9 corresponds to high probability of tuberculous peritonitis based on the visualization of all described songraphic symptoms. Based on the sum score obtained after the ultrasound scanning, a diagnostic algorithm can be proposed that clearly indicates further diagnostic and treatment strategies for each combination of sonographic symptoms, and for patients with HIV and/or pulmonary tuberculosis (Fig. 4).

\section{CONCLUSION}

The obtained integrated scale for the sonographic signs assessment is quite simple and allows the clinician to select the further tactics of diagnosis based on the ultrasound imaging results and to start the treatment in a timely manner. The proposed scheme may also complete the diagnostic search algorithm for any form of ascites or granulomatous peritonitis.

Due to the clinical symptoms non-specificity and the subacute course, the diagnosis of peritoneal tuberculosis remains a difficult task. Transabdominal ultrasound, which is affordable and commonly used in medical practice, can become a first-line screening test for verification of tuberculous peritonitis. Peritoneal tuberculosis should be taken into account in all cases of differential diagnosis of patients with unclear ascites, pulmonary tuberculosis and immunosuppression.

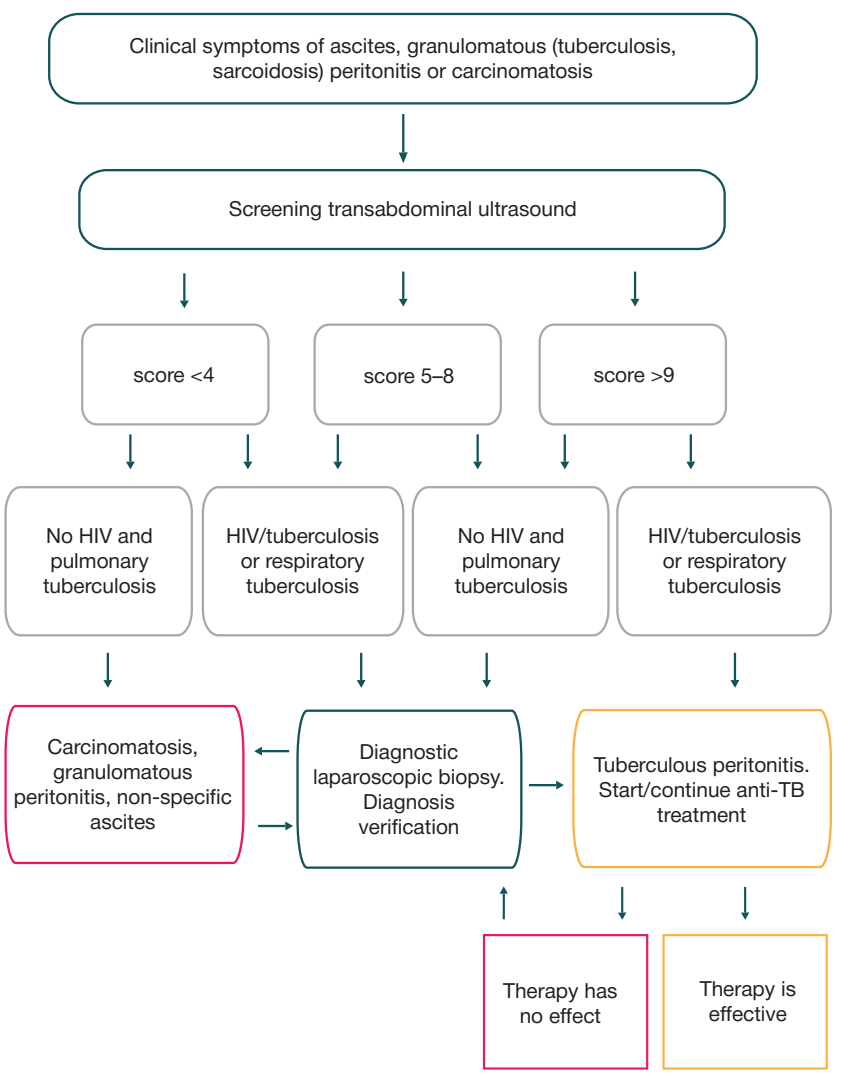

Fig. 4. Tactical algorithm for the tuberculous peritonitis diagnosis 
1. Gupta P, Kumar S, Sharma V, Mandavdhare H, Dhaka N, Sinha SK, et al. Common and uncommon imaging features of abdominal tuberculosis. Journal of Medical Imaging and Radiation Oncology. 2019; 63 (3): 329-39. DOI: 10.1111/1754-9485.12874.

2. Sinitsyn MV, Belilovsky EM, Sokolina IA, Reshetnikov MN, Tityukhina MV, Baturin OV. Extrapulmonary tuberculosis in HIV patients. Tuberculosis and Lung Diseases. 2017; 95 (11): 19-25. DOI: 10.21292/2075-1230-2017-95-11-19-25. Russian.

3. Ködmön C, Zucs P, Van der Werf MJ. Migration-related tuberculosis: Epidemiology and characteristics of tuberculosis cases originating outside the European Union and European Economic Area, 2007 to 2013. Eurosurveillance. 2016; (21): 2327. DOI: 10.2807/1560-7917.ES.2016.21.12.30164.

4. Chow KM, Chow VC, Szeto CC. Indication for peritoneal biopsy in tuberculous peritonitis. The American Journal of Surgery. 2003; (185): 567-73. DOI: 10.1016/s0002-9610(03)00079-5.

5. Plotkin DV, Sinitsyn MV, Reshetnikov MN, Kharitonov SV, Skopin MS, Sokolina IA. Tuberculous peritonitis. «Forgotten» disease. Khirurgiya. Zhurnal im. N.I. Pirogova. 2018; (12): 38-44. DOI: 10.17116/hirurgia20181213. Russian.

6. Vaid U, Kane GC. Tuberculous Peritonitis. Microbiology Spectrum. 2017; (5): 324-29. DOI: 10.1128/microbiolspec.TNMI7-0006-2016.

7. Demirkazik FB, Akhan O, Ozmen MN, Akata D. US and CT findings in the diagnosis of tuberculous peritonitis. Acta Radiologica. 1996; 37 (4): 517-20. DOI: 10.1177/02841851960373P217.

8. Portielje JE, van der Werf SD, Mutsaers JA, Lohle PN, Puylaert JB. Peritonitis tuberculosa echografisch te herkennen [Echographic recognition of tuberculous peritonitis]. Nederlands Tijdschrift voor Geneeskunde. 1997; 141 (2): 89-93.

9. Mojdunova NK, Turdumambetova GK. Ultrasound picture of abdominal tuberculosis. International journal of applied and fundamental research. 2017; (6): 111-3. Russian.

10. Vostrov AN, Mitina LA, Kazakevich VI, Kaprin AD, Stepanov SO, Guts OV, et al. Value of ultrasound in differential diagnosis of ovarian cancer with peritoneal carcinomatosis and peritoneal tuberculosis. Ultrasound and functional diagnostics. 2017; (3): 60-71. Russian.

11. Husain A, Firdaus H, Panday P. Study of Comparison of high resolution sonography and computed tomography in evaluation of abdominal tuberculosis among patients in Lucknow, Uttar Pradesh, India. International Journal of Surgery. 2018; (5): 17139. DOI: 10.18203/2349-2902.isj20181388.

12. Goodman SN. Toward Evidence-Based Medical Statistics. 2: The Bayes Factor. Annals of Internal Medicine. 1999; (130): 1005-13.

\section{Литература}

1. Gupta P, Kumar S, Sharma V, Mandavdhare H, Dhaka N, Sinha SK, et al. Common and uncommon imaging features of abdominal tuberculosis. Journal of Medical Imaging and Radiation Oncology. 2019; 63 (3): 329-39. DOI: 10.1111/1754-9485.12874.

2. Синицын М. В., Белиловский Е. М., Соколина И. А., Решетников М. Н., Титюхина М. В., Батурин О. В. Внелегочные локализации туберкулеза у больных ВИЧ-инфекцией. Туберкулез и болезни легких. 2017; 95 (11): 19-25. DOI: 10.21292/2075-1230-2017-95-11-19-25.

3. Ködmön C, Zucs P, Van der Werf MJ. Migration-related tuberculosis: Epidemiology and characteristics of tuberculosis cases originating outside the European Union and European Economic Area, 2007 to 2013. Eurosurveillance. 2016; (21): 2327. DOI: 10.2807/1560-7917.ES.2016.21.12.30164.

4. Chow KM, Chow VC, Szeto CC. Indication for peritoneal biopsy in tuberculous peritonitis. The American Journal of Surgery. 2003; (185): 567-73. DOI: 10.1016/s0002-9610(03)00079-5.

5. Плоткин Д. В., Синицын М. В., Решетников М. Н., Харитонов С. В., Скопин М. С., Соколина И. А. Туберкулезный перитонит. «Забытая» болезнь. Хирургия. Журнал им. Н. И. Пирогова. 2018; (12): 38-44. DOI: 10.17116/hirurgia201812138.

6. Vaid U, Kane GC. Tuberculous Peritonitis. Microbiology Spectrum.
13. Smereczyński A, Kołaczyk K, Bernatowicz E. Difficulties in differentiating the nature of ascites based on ultrasound imaging. Journal of Ultrasonography. 2017; 17 (69): 96-100. DOI: 10.15557/JoU.2017.0013.

14. Atzori S, Vidili G, Delitala G. Usefulness of ultrasound in the diagnosis of peritoneal tuberculosis. The Journal of Infection in Developing Countries. 2012; 6 (12): 886-90. DOI: 10.3855/ jidc.2654.

15. Weill FS, Costaz R, Guetarni S, Maltoni I, Rohmer P. Echographic diagnosis of peritoneal metastases in patients with ascites. European Journal of Radiology. 1990; (71): 365-8.

16. Stepanov SO, Mitina LA, Guts OV, Bespalov PD. Ultrasound imaging of peritoneal dissemination. Ultrasound and functional diagnostics. 2013; 3 (4): 66-70. Russian.

17. N'dri K, Gbazi GC, Konan A, Kouadio, Koffi, N'dri N, et al. Apport de l'échographie dans le diagnostic de la tuberculose péritonéale ascitique. Médecine d'Afrique Noire. 1993; (40): 503-6.

18. Dafiri R, Imani F. Tuberculose abdominale. Encycl Méd Chir (Editions Scientifiques et Médicales Elsevier SAS, Paris, tous droits réservés). Radiodiagnostic - Appareil digestif 2001; 33010-A-30: 12

19. Gastli H, Hassine W, Absesselem K, Gharbi HA. Echographic aspects of peritoneal tuberculosis. Apropos of 14 cases. European Journal of Radiology. 1983; (64): 325-9.

20. Mbengue A, Ndiaye AR, Amar N, Diallo M, et al. Ultrasonography of peritoneal tuberculosis. Journal of Ultrasonography. 2019; (19): 98-104. DOI: 10.15557/JoU.2019.0014.

21. Batra A, Gulati MS, Sarma D, Paul SB. Sonographic appearances in abdominal tuberculosis. Journal of Clinical Ultrasound. 2000; (28): 233-45. DOI: 10.1002/(sici)1097-0096(200006)28:5<233::aidjcu5>3.0.co;2-c.

22. Fall F, Ndiaye AR, Ndiaye B, Gning SB, Diop Y, Fall B. Peritoneal tuberculosis: a retrospective study of 61 cases at Principal hospital in Dakar. Journal of Gastroenterology and Hepatology. 2010; (4): 38-43.

23. Darré T, Tchaou M, Sonhaye L, Patassi AA, Kanassoua K, Tchangai B. Analyse d'une série de 44 cas de tuberculose péritonéale diagnostiqués au laboratoire d'anatomie pathologique du $\mathrm{CHU}$ Tokoin de Lomé (1993-2014). Bulletin de la Société de Pathologie Exotique. 2015; (108): 324-7.

24. Heller T, Goblirsch S, Wallrauch C, Lessells R, Brunetti E. Abdominal tuberculosis: sonographic diagnosis and treatment response in HIV positive adults in rural South Africa. International Journal of Infectious Diseases. 2010; 14 (Suppl 3): 108-12. DOI: 10.1016/j.jijd.2009.11.030.
2017; (5): 324-29. DOI: 10.1128/microbiolspec.TNMI7-0006-2016. 7. Demirkazik FB, Akhan O, Ozmen MN, Akata D. US and CT findings in the diagnosis of tuberculous peritonitis. Acta Radiologica. 1996; 37 (4): 517-20. DOI: 10.1177/02841851960373P217.

8. Portielje JE, van der Werf SD, Mutsaers JA, Lohle PN, Puylaert JB. Peritonitis tuberculosa echografisch te herkennen [Echographic recognition of tuberculous peritonitis]. Nederlands Tijdschrift voor Geneeskunde. 1997; 141 (2): 89-93.

9. Мойдунова Н. К., Турдумамбетова Г. К. Ультразвуковая картина абдоминального туберкулеза. Международный журнал прикладных и фундаментальных исследований. 2017; (6): 111-3.

10. Востров А. Н., Митина Л. А., Казакевич В. И., Каприн А. Д., Степанов С. О., Гуц О. В. и др. Возможности ультразвуковой диагностики в дифференциации поражения брюшины при раке яичников и туберкулезе. Ультразвуковая и функциональная диагностика. 2017; (3): 60-71.

11. Husain A, Firdaus H, Panday P. Study of Comparison of high resolution sonography and computed tomography in evaluation of abdominal tuberculosis among patients in Lucknow, Uttar Pradesh, India. International Journal of Surgery. 2018; (5): 17139. DOI: 10.18203/2349-2902.isj20181388. 
12. Goodman SN. Toward Evidence-Based Medical Statistics. 2: The Bayes Factor. Annals of Internal Medicine. 1999; (130): 1005-13.

13. Smereczyński A, Kołaczyk K, Bernatowicz E. Difficulties in differentiating the nature of ascites based on ultrasound imaging. Journal of Ultrasonography. 2017; 17 (69): 96-100. DOI: 10.15557/JoU.2017.0013.

14. Atzori S, Vidili G, Delitala G. Usefulness of ultrasound in the diagnosis of peritoneal tuberculosis. The Journal of Infection in Developing Countries. 2012; 6 (12): 886-90. DOI: 10.3855/ jidc.2654

15. Weill FS, Costaz R, Guetarni S, Maltoni I, Rohmer P. Echographic diagnosis of peritoneal metastases in patients with ascites. European Journal of Radiology. 1990; (71): 365-8.

16. Степанов С. О., Митина Л. А., Гуц О. В., Беспалов П. Д. Визуализация перитонеальной диссеминации при ультразвуковом исследовании. Ультразвуковая и функциональная диагностика. 2013; 3 (4): 66-70.

17. N'dri K, Gbazi GC, Konan A, Kouadio, Koffi, N'dri N, et al. Apport de l'échographie dans le diagnostic de la tuberculose péritonéale ascitique. Médecine d'Afrique Noire. 1993; (40): 503-6.

18. Dafiri R, Imani F. Tuberculose abdominale. Encycl Méd Chir (Editions Scientifiques et Médicales Elsevier SAS, Paris, tous droits réservés). Radiodiagnostic - Appareil digestif 2001; 33010-A-30: 12.
19. Gastli H, Hassine W, Absesselem K, Gharbi HA. Echographic aspects of peritoneal tuberculosis. Apropos of 14 cases. European Journal of Radiology. 1983; (64): 325-9.

20. Mbengue A, Ndiaye AR, Amar N, Diallo M, et al. Ultrasonography of peritoneal tuberculosis. Journal of Ultrasonography. 2019; (19): 98-104. DOI: 10.15557/JoU.2019.0014.

21. Batra A, Gulati MS, Sarma D, Paul SB. Sonographic appearances in abdominal tuberculosis. Journal of Clinical Ultrasound. 2000; (28): 233-45. DOI: 10.1002/(sici)1097-0096(200006)28:5<233::aidjcu5>3.0.co;2-c.

22. Fall F, Ndiaye AR, Ndiaye B, Gning SB, Diop Y, Fall B. Peritoneal tuberculosis: a retrospective study of 61 cases at Principal hospital in Dakar. Journal of Gastroenterology and Hepatology. 2010; (4): 38-43.

23. Darré T, Tchaou M, Sonhaye L, Patassi AA, Kanassoua K, Tchangai B. Analyse d'une série de 44 cas de tuberculose péritonéale diagnostiqués au laboratoire d'anatomie pathologique du $\mathrm{CHU}$ Tokoin de Lomé (1993-2014). Bulletin de la Société de Pathologie Exotique. 2015; (108): 324-7.

24. Heller T, Goblirsch S, Wallrauch C, Lessells R, Brunetti E. Abdominal tuberculosis: sonographic diagnosis and treatment response in HIV positive adults in rural South Africa. International Journal of Infectious Diseases. 2010; 14 (Suppl 3): 108-12. DOI: 10.1016/j.ijid.2009.11.030. 